\title{
Analisa Lokasi dan Perancangan Fasilitas Sisi Udara Bandar Udara Bali Utara
}

\author{
Ida Bagus Barawakya, Wahyu Herijanto, Catur Arif Prastyanto, Hera Widyastuti, dan \\ Ervina Ahyudanari
}

Departemen Teknik Sipil, Institut Teknologi Sepuluh Nopember (ITS)

Corresponding Author: ervina@ce.its.ac.id

\section{ARTIKEL INFO}

\section{Informasi Artikel}

Artikel masuk: 25-3-19

Artikel revisi: 5-8-19

Artikel diterima: 26-12-19

\begin{abstract}
ABSTRAK
Jumlah pergerakan Bandara Ngurah Rai meningkat 6,1 persen antara tahun 2016-2017. Berdasarkan RTRW Provinsi Bali akan dibangun Bandara Bali Utara di daerah Kubutambahan, Buleleng. Oleh karena itu, perlu adanya evaluasi apakah lokasi pembangunan Bandara Bali Utara sesuai dengan Kawasan Keselamatan Operasional Penerbangan dan juga merencanakan fasilitas sisi udara pada Bandara Bali Utara. Pengumpulan data angin dari tahun 2014 hingga 2018 didapat dari Iowa State University Enviromental Messonet. Dari analisa data didapat bahwa arah runway adalah $90^{\circ}$. Pada perencanaan fasilitas sisi udara dilakukan pengumpulan data pergerakan penumpang dan pesawat dari tahun 2012 hingga 2016 pada Bandara Ngurah Rai yang didapat dari PT. Angkasa Pura 2 dan Kementerian Perhubungan Udara, kemudian dilakukan regresi untuk mendapatkan data pergerakan pada 20 tahun rencana. Dari data historis tersebut dikalikan dengan presentase demand pergerakan penumpang dan pesawat di Bandara Bali Utara yang didapat dari perbandingan tingkat pertumbuhan penghunian hotel di Bali Utara. Presentase yang didapat yakni sebesar 43,3\% sehingga pergerakan penumpang pada 20 tahun rencana sebesar 18.035.382 penumpang dan pergerakan pesawat 100.194 pergerakan. Pesawat rencana yang digunakan adalah Airbus A330-200, karena pesawat ini merupakan pesawat terbesar yang beroperasi di Bandara Ngurah Rai. Dari perhitungan didapatkan pergerakan pesawat saat jam sibuk ditahun 2038 sebesar 18 pergerakan per jam. Dan presentase pesawat yang beroperasi saat jam sibuk adalah kelas B:10\%, kelas C:32\%, kelas D:58\%. Pada perencanaan ini didapatkan panjang runway adalah $3700 \mathrm{~m}$ dengan lebar runway $66 \mathrm{~m}$. Dimensi lebar taxiway $25 \mathrm{~m}$ dan lebar bahu tiap sisinya sebesar $10 \mathrm{~m}$. Letak exit taxiway sepanjang $3100 \mathrm{~m}$ dihitung dari kedua ujung runway dengan sudut $90^{\circ}$, dan luas apron sebesar $106.300 \mathrm{~m}^{2}$. Pada perencanaan tebal perkerasan menggunakan aplikasi FAARFIELD. Didapatkan bahwa tebal perkerasan lentur sebesar 0,5 $\mathrm{m}-2,5 \mathrm{~m}$ dan tebal perkerasan kaku sebesar $0,8 \mathrm{~m}-1 \mathrm{~m}$.
\end{abstract}

\section{PENDAHULUAN}

Bali adalah salah satu provinsi yang ada di Indonesia. Pulau Bali terkenal akan keindahan dan kebudayaan yang terus dipegang oleh masyarakatnya. Tidak heran apabila Pulau Bali menjadi salah satu tujuan wisata terkenal di Indonesia bahkan di dunia. Provinsi Bali memiliki jumlah penduduk lebih dari 4,2 juta jiwa. Menurut Badan Pusat Statistik (BPS) [1] kunjungan wisatawan mancanegara ke provinsi Bali selama tahun 2016 sekitar 4,92 juta jiwa, hasil ini meningkat 23,14 dari tahun sebelumnya. Wisatawan asal Australia merupakan wisatawan terbanyak yang datang ke Bali disusul wisatawan asal Cina kemudian Jepang. Sarana transportasi yang paling menunjang kedatangan wisatawan mancanegara maupun domestik datang ke Bali adalah dengan menggunakan transportasi udara.

Saat ini Bali hanya memiliki satu Bandar Udara yaitu Bandar Udara International Ngurah Rai di daerah Tuban, Badung. Menurut Humas PT Angkasa Pura 1 Bandara Ngurah Rai jumlah pergerakan pesawat selama bulan Januari hingga September 2017 mencapai 109.850 pergerakan, jumlah itu naik 6,1 persen dari tahun 2016 [2]. Dengan jumlah pergerakan pesawat yang terus meningkat maka diperlukannya pengembangan bandara tersebut. Tetapi ada beberapa hal yang menyebabkan pengembangan tersebut sulit untuk dilaksanakan antara lain lahan yang dimiliki PT Angkasa Pura 1 terbatas dan disekitar bandara Ngurah Rai terdapat pemukiman warga dan hutan bakau sehingga sulit untuk melakukan pembebasan lahan.

Oleh karena itu seperti yang tertuang dalam Rencana 
Tata Ruang Wilayah (RTRW) Provinsi Bali [3], pemerintah provinsi Bali berencana untuk membangun Bandara baru yang diberi nama Bandara International Bali Utara di daerah Utara Pulau Bali lebih tepatnya di daerah Kubutambahan, Singaraja. Bandara ini rencananya dibangun untuk membantu Bandar Udara International I Gusti Ngurah Rai dan juga sebagai upaya pemerintah dalam pemerataan pariwisata di Bali yang selama ini hanya terfokus di daerah Bali Selatan. Dalam menentukan lokasi pembangunan bandara ini perlu mempertimbangkan peraturan mengenai kawasan keselamatan operasi penerbangan (KKOP). Peraturan ini menjelaskan mengenai ruang bebas disekitar bandara agar tidak mengganggu penerbangan. Kemudian perlu juga untuk merencanakan fasilitas sisi udara pada bandara ini meliputi runway, taxiway, dan apron. Runway merupakan tempat pesawat melakukan lepas landas dan tinggal landas. Taxiway merupakan jalan yang digunakan pesawat untuk menuju apron, begitu juga sebaliknya. Dan apron adalah tempat pesawat menaikkan dan menurunkan penumpang dan juga mempersiapkan segala kebutuhan yang akan digunakan selama penerbangan. Dimana perencanaan detail fasilitas sisi udara ini membantu pergerakan pesawat secara efisien, agar pesawat yang menggunakan runway dapat sesegera mungkin meninggalkan runway menuju apron, begitu pula sebaliknya.

Perencanaan sisi udara ini sudah pernah dilakukan sebelumnya. Sehingga tahapan perencanaan dapat dilakukan sesuai dengan standard yang ada [4][5], dan [6].

\section{METODE PENELITIAN}

Langkah-langkah untuk mengerjakan studi ini dibagi menjadi 4 diagram alir yaitu diagram alir evaluasi lokasi, diagram alir prakiraan pertumbuhan lalu lintas, diagram alir perencanaan fasilitas sisi udara, diagram alir perencanaan perkerasan.

\section{A. Evaluasi Lokasi}

Untuk melakukan evaluasi lokasi pada suatu bandara ada hal-hal yang perlu diperhatikan yaitu arah runway dan kawasan keselamatan operasional penerbangan. Untuk menentukan arah runway diperlukan data kecepatan dan arah angin yang berhembus tiap jam pada daerah tersebut. Kemudian membuat diagram windrose berdasarkan data angin tersebut untuk menentukan arah runway dan juga perlu untuk melihat kemiringan topografi dari lokasi rencana bandara apakah sudah sesuai atau belum.

Untuk membuat kawasan keselamatan operasional penerbangan diperlukan data-data seperti temperature lokasi, elevasi runway, kemiringan lokasi rencana bandara, panjang runway rencana dan juga pesawat rencananya. Setelah memperoleh data-data tersebut kemudian mengklasifikasikan runway rencana berdasarkan klasifikasi runway menurut International Civil Aviation Organization [7]. Setelah menentukan klasifikasi runway kemudian menentukan dimensi dan kemiringan dari kawasan keselamatan operasional penerbangan.

Dari perhitungan arah runway dan kawasan keselamatan operasional penerbangan kemudian dilakukan evaluasi terhadap lokasi disekitar runway apakah ada yang melewati batas dari kawasan operaionl penerbangan atau tidak. Apabila ada yang melewati perlu diberi tanda seperti lampu untuk menandakan daerah yang melewati batas.

\section{B. Prakiraan Pertumbuhan Lalu Lintas}

Prakiraan pergerakan pesawat dan penumpang di Bandara Bali Utara menggunakan data historis di Bandara Ngurah Rai. Data historis yang didapat kemudian diprakirakan menggunakan metode regresi sehingga akan didapat pergerakan pesawat dan penumpang 20 tahun mendatang di Bandara Ngurah Rai.

Setelah itu dilakukan perbandingan terhadap pertumbuhan tingkat hunian hotel di Bali Utara sehingga akan didapatkan pergerakan pesawat dan penumpang di Bandara Bali Utara pada 20 tahun mendatang.

\section{Perencanaan Fasilitas Sisi Udara}

Fasilitas sisi udara yang akan direncanakan meliputi runway, taxiway, exit taxiway, dan apron. Untuk merencanakan runway dibutuhkan data-data mengenai kemiringan runway, elevasi runway, temperature dan juga spesifikasi teknis pesawat rencana yang akan beroperasi. Setelah itu dilakukan perhitungan untuk mendapatkan panjang rencana runway. Kemudian mengklasifikasin runway rencana berdasarkan International Civil Aviation Organization. Untuk dimensi lebar runway dan shoulder runway didapatkan sesuai dengan klasifikasi runway rencana.

Pada perencanaan taxiway meliputi dimensi taxiway dan shoulder taxiway didapatkan berdasarkan klasifikasi runway rencana. Untuk merencanakan exit taxiway diperlukan data kecepatan dan perlambatan pesawat rencana dan juga pergerakan pesawat jam puncak pada 20 tahun rencana sehingga akan didapatkan apakah exit taxiway yang digunakan adalah rapid exit taxiway atau regular exit taxiway.

Pada perencanaan apron diperlukan data mengenai pergerakan pesawat saat jam puncak pada 20 tahun rencana, persentase komposisi pergerakan pesawat masing-masing kategori pada 20 tahun rencana, dan juga waktu penggunaan apron masing-masing kategori pesawat. Dari data tersebut dilakukan perhitungan untuk mendapatkan jumlah gate masing-masing kategori pesawat. Kemudian dilakukan perhitungan untuk mendapatkan luas apron rencana dengan menggunakan data spesifikasi teknis pesawat masing-masing kategori dan juga jumlah gate masing-masing kategori pesawat.

\section{Perencanaan Perkerasan}

Pada perencanaan tebal perkerasan data yang diperlukan adalah data tanah meliputi nilai California Bearing Ratio dan juga nilai modulus tanah (k), jumlah keberangkatan tiap jenis pesawat yang akan beroperasi pada 20 tahun rencana, persentase pertumbuhan jumlah keberangkatan, dan juga berat maksimum saat lepas landas tiap jenis pesawat yang akan beroperasi pada 20 tahun rencana. Metode yang digunakan dalam merencanakan tebal perkerasan adalah metode Federal Aviation Administration [8] dengan bantuan program aplikasi FAARFIELD. 


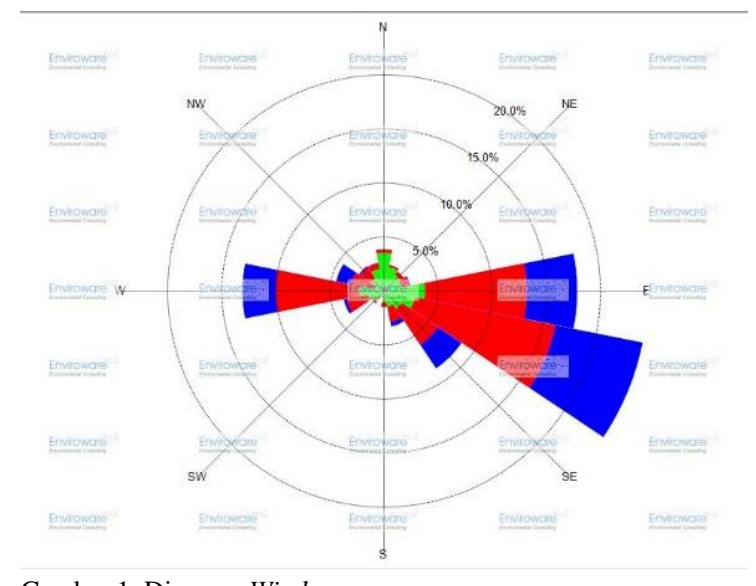

Gambar 1. Diagram Windrose.

\section{HASIL DAN PEMBAHASAN}

\section{A. Analisis Data Angin}

Sebelum menentukan Kawasan Keselamatan Operasional Penerbangan (KKOP), perlu direncanakan arah runway. Untuk merencanakan arah runway diperlukan data angin yang berhembus di daerah tersebut.

Untuk data angin didapat dari Iowa State University Enviromental Messonet [9]. Dalam perencanaan ini diambil data angin dari tanggal 1 Januari 2014 sampai 24 Maret 2018. Selanjutnya data yang didapat diolah menggunakan aplikasi WRPLOT untuk mendapatkan diagram windrose (Gambar 1).

Persyaratan ICAO, pesawat dapat mendarat atau lepas landas pada sebuah lapangan terbang pada $95 \%$ dari waktu komponen crosswind tidak melebihi : [7]

1. 20 knots dengan ARFL $\geq 1500 \mathrm{~m}$

2. 13 knots dengan ARFL antara $1200 \mathrm{~m}-1499 \mathrm{~m}$

3. 10 knots dengan ARFL $<1200 \mathrm{~m}$

Dari hasil Analisa dengan aplikasi windrose dan juga melihat kondisi lapangan didapat bahwa arah runway rencana adalah $90^{\circ}$ dengan crosswind maximum dari kiri sebesar 15,6 knot dan dari kanan sebesar 16 knot.

\section{B. Perencanaan KKOP}

Runway Bandara Bali Utara rencananya akan dibangun sepanjang 4100 meter. Suhu di daerah buleleng sekitar $28^{\circ} \mathrm{C}$, ketinggian runway terhadap muka air laut adalah 24 meter dihitung dari aplikasi google earth dan efektif gradiennya adalah $3,3 \%$ dihitung menggunakan aplikasi google earth, sehingga ARFL sebesar 3047 m berdasarkan klasifikasi runway ICAO termasuk golongan 4E dan pada tabel KKOP termasuk precision II dan III [7]. (Gambar 2)

\section{Forecasting (Prakiraan)}

Prakiraan pergerakan pesawat dan penumpang di Bandara Bali Utara diperhitungkan menggunakan data historis di Bandara Ngurah Rai dari tahun 2012 hingga 2016. Tabel 1 adalah data pergerakan pesawat dan penumpang yang didapat dari majalah PT. Angkasa Pura I dan website kementerian perhubungan udara.

Dari data historis pada Tabel 1 kemudian dilakukan peramalan menggunakan metode regresi linear, polynomial, logaritmik, dan exponensial. Kemudian dipilih hasil yang paling mendekati dengan data pada tahun terakhir yaitu tahun 2016

Dari hasil perhitungan pada Tabel 2 dan 3 didapat hasil yang paling pendekati adalah regresi linear. Sehingga dari hasil regresi linear didapat prakiraan pergerakan pesawat

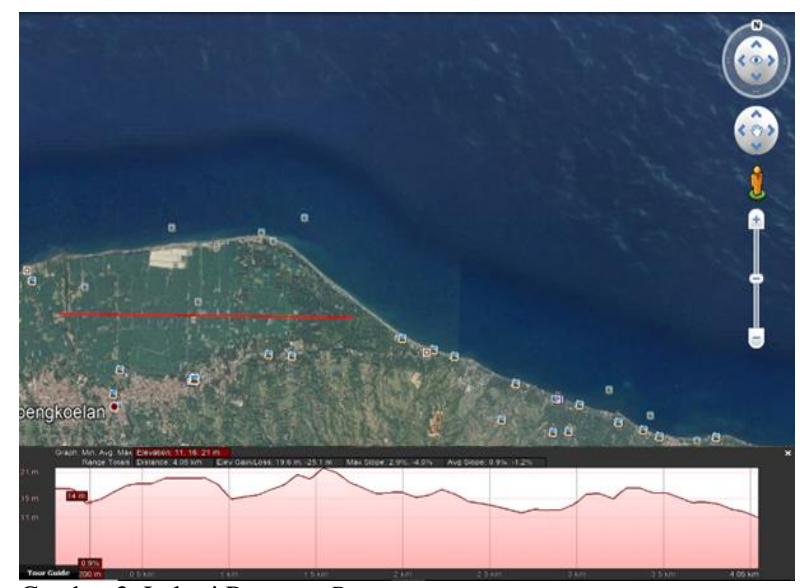

Gambar 2. Lokasi Rencana Runway.

pada tahun 2038 adalah 231.394 pergerakan dan pergerakan penumpang pada tahun 2038 adalah 41.620.110 penumpang.

Untuk mendapatkan pergerakan penumpang dan pesawat pada tahun 2038 di Bandara Bali Utara adalah dengan membagi hasil prakiraan pada Bandara Ngurah Rai dengan presentase tingkat pertumbuhan penghunian hotel di Bali Utara.

Data tingkat hunian di Bali Utara didapatkan dari Badan Pusat Statistik Provinsi Bali dari tahun 2007-2015. Presentase Tingkat Hunian Hotel di Provinsi Bali ditunjukkan pada Tabel 4 [10].

Dari data pada Tabel 4 kemudian dilakukan perhitungan dengan regresi exponensial, sehingga didapat persentase tingkat penghunian hotel di daerah bali utara sebesar 1,3\%. Hasil tersebut kemudian dibagi dengan persentase tingkat penghunian hotel di Provinsi Bali sebesar 3\% sehingga didapat tingkat pertumbuhan penumpang pada Bandara Bali Utara sebesar 43,3\%. Hasil tersebut kemudian dikalikan dengan jumlah pergerakan penumpang dan pesawat di Bandara Ngurah Rai, sehingga didapatkan pergerakan penumpang di Bandara Bali Utara tahun 2038 sebesar 18.035.382 pergerakan dan pergerakan pesawat sebesar 100.194 pergerakan.

\section{Perencanaan Runway}

Direncanakan pesawat beroperasi di Bandara Bali Utara sama dengan di Bandara Ngurah Rai. Pesawat yang memiliki ARFL terpanjang yang beroperasi di Bandara Ngurah Rai adalah Airbus A330-200. Berikut adalah spesifikasi teknis dari Airbus A330-200:

1. ARFL

2. Wingspan

3. Overall Length

$: 2713 \mathrm{~m}$

: $60,3 \mathrm{~m}$

: $59 \mathrm{~m}$

4. OMGWS (Outer Main Gear Wheel Span) : $12 \mathrm{~m}$

5. MTOW (Maximum Take Off Weight) : $230000 \mathrm{~kg}$

Untuk menentukan panjang runway yang terkoreksi maka perlu dilakukan perhitungan koreksi ARFL pesawat terhadap elevasi, temperature, dan kemiringan landasan (slope). Data-data kondisi lapangan sebagai berikut:

1. Elevasi diatas muka air laut $: 24 \mathrm{~m}$

2. Temperatur $: 26^{\mathrm{O} C}$

3. Kemiringan landasan $: 3,3 \%$

4. Faktor koresi elevasi $(\mathrm{Fe}) \quad: 1,00056$

5. Faktor koreksi suhu (Ft) $\quad: 1,011156$

6. Faktor koreksi slope (Fs) $\quad: 1,33$

Sehingga panjang runway rencana dihitung menggunakan rumus: [11] 
Tabel 1. Data Historis Pergerakan Penumpang dan Pesawat

\begin{tabular}{cccc}
\hline \multicolumn{2}{c}{ Pergerakan Pesawat } & \multicolumn{2}{c}{ Pergerakan Penumpang } \\
Tahun & Jumlah & Tahun & Jumlah \\
\hline 2012 & 113.542 & 2012 & 14.175 .550 \\
2013 & 124.555 & 2013 & 15.631 .839 \\
2014 & 130.149 & 2014 & 17.271 .415 \\
2015 & 126.337 & 2015 & 17.108 .387 \\
2016 & 139.106 & 2016 & 20.001 .275 \\
\hline
\end{tabular}

Tabel 2. Hasil Perhitungan Regresi pada Data Pergerakan Pesawat

\begin{tabular}{cc}
\hline Regresi & Hasil \\
\hline Linear & 134640,5 \\
Logaritmik & 134636,9 \\
Exponensial & 148115,8 \\
Polynomial & 116109,3 \\
\hline
\end{tabular}

Tabel 3. Hasil Perhitungan Regresi Pada Data Pergerakan Penumpang

\begin{tabular}{cc}
\hline Regresi & Hasil \\
\hline Linear & 18656319 \\
Logaritmik & 18655225 \\
Exponensial & 13667896 \\
Polynomial & 16632173 \\
\hline
\end{tabular}

Panjang runway $=$ ARFL $x$ Ft $x$ Fs $x$ Fe

Panjang runway $=2713 \times 1,00056 \times 1,011156 \times 1,33$

Panjang runway $=3650,6 \mathrm{~m}=3700 \mathrm{~m}$

Sesuai dengan tabel aircraft design grup berdasarkan ICAO. Maka didapat lebar runway untuk pesawat Airbus A330-200 adalah $45 \mathrm{~m}$.

Berdasarkan tabel ICAO, ketentuan runway shoulder untuk pesawat grup $\mathrm{V}$ E adalah 10,5 m dengan kemiringan maksimum shoulder $2,5 \%$.

\section{E. Perencanaan Taxiway}

Dalam perhitungan taxiway perlu diperhatikan roda terluar dari pesawat rencana yang menggunakan taxiway harus bebas dari hambatan apapun.

Berdasarkan ketentuan SKEP 77-VI-2005 Dirjen Perhubungan[13] untuk code letter E dan golongan pesawat $\mathrm{V}$, lebar taxiway yang dibutuhkan sebesar $25 \mathrm{~m}$ dan jarak bebas minimum dari sisi terluar roda utama dengan tepi taxiway adalah 4,5 m .

Dalam ketentuan lebar bahu taxiway untuk code letter $\mathrm{E}$ memiliki lebar minimum bahu sebesar 44 meter. Lebar tersebut sudah termasuk lebar taxiway dalam perhitungan sebelumnya sebesar $25 \mathrm{~m}$, sehingga lebar bahu taxiway tiap sisinya didapat sebesar $10 \mathrm{~m}$.

Exit taxiway diperlukan sebagai jalan penghubung antara runway ke taxiway, dalam perencanaannya jarak dan sudut exit taxiway bervariasi tergantung tipe pesawat yang membutuhkannya. Data kecepatan dan perlambatan tiap tipe pesawat ditunjukkan pada Tabel 5.

Untuk perhitungan jaraknya diperoleh dari jarak ujung runway ke titik touchdown (D1). Dan dari titik touchdown ke exit taxiway (D2). Rumus yang digunakan sebagai berikut [11].

$\mathrm{D} 1=\frac{\mathrm{Vot}^{2}-\mathrm{Vtd}^{2}}{2 \mathrm{a} 1} ; \mathrm{D} 2=\frac{\mathrm{Vtd}^{2}-\mathrm{Ve}^{2}}{2 \mathrm{a} 2}$
$\mathrm{D}=\mathrm{D} 1+\mathrm{D} 2$

Jarak titik touchdown ke exit taxiway harus ditambahkan factor koreksi temperature dan elevasi terhadap muka air laut. Menggunakan data kondisi lapangan yang sama didapat faktor koreksi elevasi adalah 1,0024 dan faktor koreksi suhu adalah 1,019643. Hasil perhitungan jarak total dari ujung runway ke lokasi exit taxiway ditunjukkan pada Tabel 6.
Tabel 4. Presentase Tingkat Hunian Hotel di Provinsi Bali

\begin{tabular}{ccc}
\hline Tahun & Wilayah Utara & Wilayah Selatan \\
\hline 2007 & 6.266 & 33.734 \\
2008 & 8.779 & 47.821 \\
2009 & 8.895 & 44.155 \\
2010 & 9.628 & 45.752 \\
2011 & 8.907 & 46.473 \\
2012 & 8.485 & 46.945 \\
2013 & 8.460 & 45.890 \\
2014 & 7.705 & 43.275 \\
2015 & 7.644 & 43.956 \\
\hline
\end{tabular}

\begin{tabular}{cccccccc}
\multicolumn{1}{c}{ Tabel 5. Tabel Kecepatan dan Perlambatan } \\
\hline $\begin{array}{c}\text { Kategori } \\
\text { Pesawat }\end{array}$ & \multirow{2}{*}{ Vot } & \multirow{2}{*}{ Vtd } & 30 & Ve & 90 & a1 & a2 \\
\hline A & 46,94 & 44,17 & 30,9 & 20,58 & 7,72 & 0,76 & 1,52 \\
B & 61,67 & 50 & 30,9 & 20,58 & 7,72 & 0,76 & 1,52 \\
C & 71,94 & 61,67 & 30,9 & 20,58 & 7,72 & 0,76 & 1,52 \\
D & 85 & 71,94 & 30,9 & 20,58 & 7,72 & 0,76 & 1,52 \\
E & 79,7 & 77,1 & 30,9 & 20,58 & 7,72 & 0,76 & 1,52 \\
\hline
\end{tabular}

Tabel 6. Jarak dari Ujung Runway ke Exit Taxiway

\begin{tabular}{cccc}
\hline Kategori & \multicolumn{3}{c}{ D } \\
Pesawat & 30 & 45 & 90 \\
\hline A & 501,59 & 679,59 & 801,95 \\
B & 1377,50 & 1555,50 & 1677,86 \\
C & 1861,03 & 2039,03 & 2161,39 \\
D & 2768,08 & 2946,07 & 3068,44 \\
E & 1946,41 & 2124,40 & 2246,77 \\
F & 2037,35 & 2215,35 & 2337,71 \\
\hline
\end{tabular}

Berdasarkan jumlah pergerakan dan tipe pesawat yang akan beroperasi di Bandara Bali Utara maka exit taxiway yang dipilih exit taxiway untuk kategori pesawat D. Sudut exit taxiway yang akan dipakai adalah sudut $90^{\circ}$, karena lalu lintas rencana pada jam puncak kurang dari 26 pergerakan. Sehingga jarak minimum exit taxiway yang dipakai pada perencanaan ini adalah sebesar 3068 meter yang diukur dari kedua ujung runway.

\section{F. Perencanaan Apron}

Pergerakan pesawat pada saat peak hour di tahun 2038 yang didapat pada perhitungan sebelumnya yaitu sebesar 18 pergerakan per jam. Dan dengan presentase pergerakan masing-masing kategori pesawat yaitu pesawat kategori B: $10 \%$, C: 32\%, D: 58\%. Maka didapat jumlah gate yang dibutuhkan dengan persamaan.

$$
\mathrm{G}=\frac{V x T}{u}
$$

1. $\mathrm{T}$ yang dipakai adalah waktu pemakain gate tiap kategori pesawat yaitu kategori B: 40 menit, C: 30 menit, D: 20 menit.

2. Faktor utilitas yang dipakai sebesar 0,8

Sehingga didapat jumlah gate untuk kategori B: 2 buah, kategori C: 4 buah, dan kategori D: 4 buah. Untuk menghitung panjang dan lebar apron digunakan rumus sebagai berikut:

Panjang apron $=$ jumlah gate $\times 2 R+($ jumlah gate +1$) \times C$

Lebar apron $=\mathrm{L}+\mathrm{C}+\mathrm{W}$

\section{Keterangan:}

$\mathrm{R} \quad=$ radius putar pesawat $(\mathrm{m})$

$\mathrm{L} \quad=$ panjang pesawat $(\mathrm{m})$

$\mathrm{W}=$ lebar taxilane $(48,76 \mathrm{~m}$ untuk pesawat kecil dan 88,39 m untuk pesawat berbadan lebar)

$\mathrm{C}=$ Clearance (jarak pesawat ke pesawat dan pesawat ke terminal). 
Tabel 7. Hasil Perhitungan Apron

\begin{tabular}{cccc}
\multicolumn{4}{c}{ Tabel 7. Hasil Perhitungan Apron } \\
\hline \multirow{2}{*}{ Kategori Pesawat } & B & C & D \\
& ATR 72 & A 320 & B 777-300ER \\
\hline Wingspan (m) & 27,05 & 33,50 & 64,80 \\
Wheelbase (m) & 4,10 & 12,50 & 11,00 \\
Overall Length (m) & 27,22 & 37,50 & 73,90 \\
R (m) & 15,89 & 23,97 & 38,75 \\
Panjang Apron (m) & 55,18 & 193,26 & 377,26 \\
Lebar Apron (m) & 78,98 & 130,39 & 169,79 \\
Luas Apron (m $\left.{ }^{2}\right)$ & & 106236,81 \\
\hline
\end{tabular}

Tabel 8. Pertumbuhan dan Jumlah kedatangan pada tahun 2038

\begin{tabular}{cccc}
\hline Jenis Pesawat & Pertumbuhan & Jumlah* & MTOW $(\mathrm{kg})$ \\
\hline B737-800 & $2,70 \%$ & 29343 & 70535 \\
B737-500 & $2,70 \%$ & 10909 & 52390 \\
B737-900 & $2,70 \%$ & 19858 & 85000 \\
B777-300ER & $2,70 \%$ & 6924 & 351500 \\
B787-8 & $2,70 \%$ & 3200 & 79000 \\
A330-200 & $2,70 \%$ & 2581 & 230000 \\
A330-200 & $2,70 \%$ & 12330 & 230000 \\
A320 & $2,70 \%$ & 44664 & 72000 \\
ATR72 & $2,70 \%$ & 12064 & 228000 \\
CRJ 1000 & $2,70 \%$ & 1871 & 40824 \\
\hline
\end{tabular}

*Jumlah : Jumlah Keberangkatan Tahun 2038

Sehingga didapatkan luas apron luas apron seperti ditunjukan Tabel 7.

\section{G. Perencanaan Perkerasan Sisi Udara}

Dalam perencanaan perkerasan sisi udara metode yang digunakan adalah metode FAA [8] dengan bantuan program FAARFIELD. Data yang diperlukan adalah data pertumbuhan dan jumlah keberangkatan tiap jenis pesawat pada tahun 2038 dan MTOW tiap jenis pesawat seperti yang ditunjukkan pada Tabel 8 .

\section{Perkerasan Lentur}

Perkerasan ini untuk mendesain tebal perkerasan runway dan taxiway. Karena keterbatasan mendapatkan data tanah maka nilat CBR tanah dibuat range antara 0,7\%-33,3\%, sehingga hasil perhitungan tebal perkerasan lentur akan seperti grafik yang ditunjukkan pada Gambar 3.

Dari hasil perhitungan didapat tebal perkerasan lentur rencana dari $0,4 \mathrm{~m}-2,5 \mathrm{~m}$.

2. Perkerasan Kaku (Rigid)

Perkerasan ini untuk mendesain tebal perkerasan pada apron. Karena keterbatasan mendapatkan data tanah, maka nilai k dipakai range antara 21 pci-440 pci, sehingga perhitungan tabel perkerasan kaku akan seperti grafik yang ditunjukkan pada Gambar 4.

Sehingga dari hasil perhitungan didapatkan tebal perkerasan kaku rencana dari $0,8 \mathrm{~m}-1 \mathrm{~m}$.

\section{KESIMPULAN}

1. Berdasarkan hasil analisa data angin dan perencanaan KKOP didapatkan bahwa pada $10 \mathrm{~km}$ arah selatan runway terdapat dataran yang tingginya melebihi batas kawasan horizontal luar sehingga perlu diberikan tanda berupa lampu pada dataran tersebut.

2. Dari data pergerakan lalu lintas udara yang beroperasi di Bandara Ngurah Rai dan sudah dikalikan dengan persentase pertumbuhan tingkat penghunian hotel di Bali Utara sebesar 43,3\% maka didapatkan pergerakan pesawat pada tahun 2038 di Bandara Bali Utara sebesar 100.194 pergerakan dan pergerakan penumpang sebesar 18.035.382 pergerakan. Dari hasil perhitungan peak hour rencana pada total pergerakan di tahun 2038 didapatkan 18 pergerakan per jam dengan komposisi pesawat kategori B: $10 \%$, kategori C: $32 \%$, kategori D: $58 \%$.

3. Berdasarkan Analisa geometrik landasan didapatkan

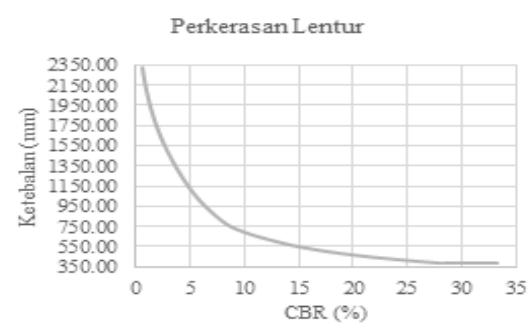

Gambar 3. Grafik tebal perkerasan lentur.

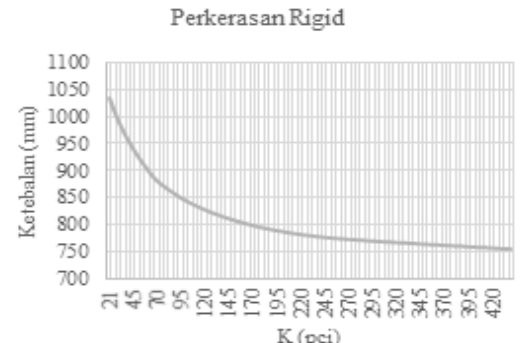

Gambar 4. Grafik tebal perkerasan rigid.

panjang landasan $3.700 \mathrm{~m}$ dengan lebar $81 \mathrm{~m}$ dilengkapi bahu landasan. Untuk lebar taxiway sebesar 45 meter dilengkapi bahu taxiway sebesar $10 \mathrm{~m}$ disetiap sisi dan dari perhitungan letak taxiway berada sejauh $3.086 \mathrm{~m}$ dihitung dari kedua ujung runway dengan sudut $90^{\circ}$. Sementara luas apron yang diperlukan adalah sebesar $106.300 \mathrm{~m}^{2}$.

4. Berdasarkan perhitungan tebal perkerasan menggunakan program FAARFIELD didapatkan untuk tebal perkerasan lentur dari $0,4 \mathrm{~m}-2,5 \mathrm{~m}$ dan tebal perkerasan kaku dari $0,8 \mathrm{~m}-2,5 \mathrm{~m}$

\section{DAFTAR PUSTAKA}

[1] NUSABALI.com, "NUSABALI.com - Kunjungan Wisman ke Bali Tembus 4 Juta Lebih." [Online]. Available: https://www.nusabali.com/berita/19546/kunjungan-wismanke-bali-tembus-4-juta-lebih. [Accessed: 20-Mar-2019].

[2] A. Dhae, "Daerah | Ratusan Pesawat Mendarat namun Bandara Bali hanya Punya Runway Tunggal," 2017. [Online]. Available: http://news.metrotvnews.com/read/2017/10/08/769930/ratusan -pesawat-mendarat-namun-bandara-bali-hanya-punya-runwaytungga. [Accessed: 20-Mar-2019].

[3] Pemerintah Provinsi Bali, "Peraturan Daerah Provinsi Bali No. 16 Tahun 2009," Bali, 2009.

[4] F. Apriana, F. Jansen, and E. M. Lintong, "PERENCANAAN PENGEMBANGAN SISI UDARA BANDAR UDARA MUTIARA SIS AL-JUFRI DI KOTA PALU PROVINSI SULAWESI TENGAH," J. SIPIL STATIK, vol. 5, no. 6, Jul. 2017.

[5] E. N. Primashanti, "Perencanaan Fasilitas Sisi Udara Terminal 3 Bandar Udara Juanda, Surabaya,” Jul. 2017.

[6] B. Nufa, "Studi Perencanaan Geometrik dan Pekerasan Sisi Udara Bandar Udara Trunojoyo Sumenep," 2017.

[7] C. Aviation Authority of New Zealand, "ICAO - International Standards - Aerodromes - Annex 14 Vol 1 Amendment 11.”

[8] F. Airport Engineering Division, "AC 150/5320-6E, Airport Pavement Design and Evaluations, 30 September 2009," 2009.

[9] Iowa State University Enviromental Messonet, "IEM :: Site Wind Roses." [Online]. Available: http://mesonet.agron.iastate.edu/sites/windrose.phtml?network =WI_ASOS\&station=CWA. [Accessed: 20-Mar-2019].

[10] Badan Pusat Statistik Provinsi Bali, "Tingkat Penghunian Kamar Akomodasi Provinsi Bali 2015," 2015. [Online]. Available:

https://bali.bps.go.id/publication/2016/07/14/d7ddb71421a391 bd191c10da/tingkat-penghunian-kamar-akomodasi-provinsibali-2015.html. [Accessed: 20-Mar-2019].

[11] R. Horonjeff, F. McKelvey, W. Sproule, and S. Young, Planning and design of airports, Fifth Edition. New York: McGraw-Hill Education, 2010. 